\title{
System opieki społecznej w okresie Polski Ludowej (lata 1944-1989). Zarys problematyki
}

\begin{abstract}
The social welfare system in the period of the Polish People's Republic (1944-1989) Outline of the subject.

In the Polish People's Republic (1944-1989), a number of organisational and ideological changes were made in the social welfare sector: most of the ways of organising help that were tested during the interwar period were replaced with new concepts, often with sad consequences for those in need. This article presents the changes that took place in the Polish social security sector in the decades after World War II. Subsequent attempts to reform the social welfare system have been shown with the use of archival materials, other historical sources and literature on the subject.
\end{abstract}

Keywords: social welfare, social assistance, history of social assistance, social welfare in the Polish People's Republic, history of social work

\section{Okres ratownictwa społecznego w latach 1944-1947}

Po zakończeniu II wojny światowej część państw Europy Środkowej znalazła się w strefie wpływów ZSRR, wśród nich były wschodnie Niemcy, Polska, Czechosłowacja, Węgry, Jugosławia, Bułgaria i Rumunia. W ciągu kilku lat władzę w tych krajach objęły rządy komunistyczne, które dążyły do podporządkowania niemalże wszystkich dziedzin życia społecznego ideom socjalistycznym.

W pierwszym okresie Polski Ludowej, tj. latach 1944-1948 rozpoczęto proces zasadniczego przekształcania ustroju społecznego. Deklaracje propagandowe władz komunistycznych podkreślały konieczność poprawy sytuacji życiowej obywateli, zwłaszcza chłopów i robotników ${ }^{1}$, ale także zabezpieczenie ludności przed głodem, bezrobociem,

\footnotetext{
${ }^{1}$ Manifest demokratycznych organizacji społeczno-politycznych $i$ wojskowych $w$ Polsce, w: Protokót Pierwszego Plenarnego Posiedzenia Krajowej Rady Narodowej, Warszawa 31 XII 1943 r. - 1 I 1944 r., s. I-VII;
} 
nędzą, analfabetyzmem i bezdomnością. Wskazywano przy tym na konieczność zerwania $\mathrm{z}$ tradycjami przedwojennymi, które budowane były w ustroju kapitalistycznym, w oparciu m.in. o własność prywatną.

Struktury powojennego systemu opieki społecznej rozpoczęto tworzyć już w lipcu 1944 r., kiedy rozpoczął prace samozwańczy, utworzony przez Stalina rząd komunistyczny o nazwie Polski Komitet Wyzwolenia Narodowego. W jego strukturach znajdował się Resort Pracy, Opieki Społecznej i Zdrowia. Podlegały mu Wojewódzkie Wydziały Opieki Społecznej na terenach wówczas wyzwolonych spod okupacji niemieckiej. Obowiązującą wówczas i w całym okresie PRL podstawą prawną regulującą kwestie opieki społecznej była Ustawa o opiece społecznej z $1923 \mathrm{r}$.

W dniu 7 grudnia 1944 powstał podległy ministerstwu Centralny Komitet Opieki Społecznej (CKOS)², który przejął nadzór nad instytucjami opieki społecznej. Nowo powołana jednostka miała zastąpić organizację z czasów II wojny światowej - Radę Główną Opiekuńczą (RGO), działającą na warunkach określonych przez okupanta niemieckiego.

Opieka społeczna w pierwszych latach Polski Ludowej miała charakter ratownictwa społecznego, którym określa się pomoc doraźną dla osób, które ucierpiały na skutek wojny, rozpoczętą po zakończeniu działań wojennych, a trwającą do roku 1948. Opieka społeczna w tym czasie była skoncentrowana na zaspokajaniu podstawowych potrzeb ludności, szczególnie w środowiskach dotkniętych zniszczeniami wojennymi ${ }^{3}$. Obejmowała ona m.in. zapewnienie: żywności, ochrony zdrowia, mieszkania, oświaty oraz miejsca pracy ${ }^{4}$. Skala pomocy doraźnej udzielanej po zakończeniu wojny była niespotykana w dziejach polskich służb społecznych i objęła co czwartego Polaka, czyli łącznie ponad sześć milionów osób ${ }^{5}$. Istotnym elementem opieki społecznej tego okresu była pomoc z zagranicy w formie żywności, odzieży, nasion zbóż do siewu, środków czystości, zabawek i in. Miała ona formę wsparcia udzielanego przez rządy wielu krajów, a także zagraniczne towarzystwa charytatywne. Wśród kilkunastu dużych organizacji międzynarodowych niosących pomoc Polakom w latach powojennych największą rolę odegrała United Nations Relief and Rehabilitation Administration (skrót UNRRA) ${ }^{6}$.

Pilna potrzeba wykwalifikowanej kadry do pracy w instytucjach opieki społecznej zmotywowała niektóre instytucje charytatywne, a także władze miast, do organizowania dorywczych kursów w tym zakresie ${ }^{7}$. Z czasem utworzono centra szkoleniowe - 1 czerw-

Protokót Pierwszego Plenarnego Posiedzenia Krajowej Rady Narodowej odbytego dnia 31 grudnia 1943 r. i w nocy z dnia 31 grudnia 1943 r. na 1 stycznia 1944 r., w: Protokót Pierwszego Plenarnego Posiedzenia..., s. $2-4 \mathrm{n}$.

2 Właściwy minister miał prawo dokonywać zmian personalnych na wszystkich szczeblach.

${ }^{3}$ K. Wódz, Stużby społeczne w Polsce. Geneza, kierunki rozwoju, metody pracy, Katowice 1982, s. 28.

4 Poradnik Pracownika Socjalnego, pod red. Jana Rosnera, Warszawa 1973, s. 20.

5 Z. Czyżowska, Świadczenia socjalne w czterdziestoleciu PRL, Warszawa 1987, s. 108; M. Karczewski, Opieka społeczna, w: Polityka społeczna, pod red. A. Rajkiewicza, Warszawa 1979, s. 501.

${ }^{6}$ Zob. M. Brenk, Działania z zakresu ratownictwa społecznego $w$ Polsce $w$ latach 1944-1948, „Biuletyn Historii Wychowania” 2014 (32), s. 145-160.

7 Opieka Społeczna 1944-1947, Wydawnictwo MPiOS, [1948], Archiwum Akt Nowych, zespół Ministerstwo Pracy i Opieki Społecznej w Warszawie, numer zespołu 402/0, sygn. 263, s. 34. 
ca 1945 r. otwarto pierwszą instytucję stałą w postaci Centrum Szkolenia Pracowników Opieki Społecznej w Łodzi, którego wykładowcami byli praktycy pracy opiekuńczej oraz wykładowcy akademiccy z okresu przedwojennego, m.in. Helena Radlińska ${ }^{8}$.

W zakresie rozwoju bazy naukowej opieki społecznej kontynuowano tradycję przedwojenną. Na powołanym w maju 1945 r. Uniwersytecie Łódzkim Helena Radlińska zorganizowała pierwszą w powojennej Polsce Katedrę Pedagogiki Społecznej, gdzie środowisko pedagogów społecznych i polityków społecznych tworzyły m.in. osoby związane w przeszłości z Wolną Wszechnicą Polską. Personalny związek z tradycją II RP pozwala na stwierdzenie, iż można mówić o kontynuacji przedwojennej szkoły pedagogiki społecznej. Kontynuowano tematykę badawczą oraz zachowano ciągłość studiów, rozpoczętych przed wojną w Studium Pracy Społeczno-Oświatowej, na kierunkach prowadzonych przez Katedrę Pedagogiki Społecznej. Konsolidacji środowiska pedagogów społecznych sprzyjał również pierwszy zjazd słuchaczy Studium Pracy Społeczno-Oświatowej Wolnej Wszechnicy Polskiej oraz Katedry Pedagogiki Społecznej, który odbył się w 1947 r9 . Obok Heleny Radlińskiej pracę we wspomnianej katedrze podjęli wtedy m.in. jej przyszli następcy (na funkcji kierownika): Aleksander Kamiński oraz Irena Lepalczyk. W roku 1947 z katedrą związał się Ryszard Wroczyński, który po trzech latach uzyskał habilitację z zakresu pedagogiki społecznej, stając się drugim (obok H. Radlińskiej) samodzielnym pracownikiem naukowym tej dyscypliny ${ }^{10}$. Wśród wybitnych naukowców spoza katedry, którzy prowadzili zajęcia, byli m.in.: Sergiusz Hessen, Maria Librachowa, Bogdan Suchodolski, Józef Chałasiński, Wiktor Wąsik, Stefan Baley, Maria i Stanisław Osowscy $^{11}$.

\section{Próba likwidacji opieki społecznej (lata 1948-1956)}

Umocnienie się władzy ludowej w Polce, w stopniu pozwalającym jej bezwzględnie kontrolować życie społeczne i polityczne dokonało się w latach 1947-1948. W tym okresie wyeliminowano z bezpośredniego wpływu na rządzenie Polską polityków opozycyjnych wobec partii komunistycznych. W grudniu 1948 r. powstała Polska Zjednoczona Partia Robotnicza (PZPR), która w sposób autorytarny rządziła Polską do 1989 r.

Komuniści wprowadzili w Polsce tzw. demokrację ludową, której główne założenia opierały się na objęciu państwowym monopolem możliwie wszystkich dziedzin życia społecznego przez m.in.: eliminację sektora prywatnego, likwidację pozarządowych or-

8 Sprawozdanie z działalności Centrum Szkolenia Pracowników Opieki Społecznej w Łodzi za okres od dnia 15 maja 1945 r. do dnia 1 grudnia 1947 r., Archiwum Akt Nowych, zespół Ministerstwo Pracy i Opieki Społecznej w Warszawie, sygn. 134, s. 4-38.

${ }^{9}$ M. Cichosz, Pedagogika społeczna w Polsce w latach 1945-2005. Rozwój-obszary refleksji i badańkoncepcje, Toruń 2006, s. 30.

${ }^{10}$ B. Smolińska-Theiss, Pytania o pedagogike spoleczna w PRL, w: Pedagogika społeczna. Tradycjateraźniejszość - nowe wyzwania, pod red. E. Trempały, M. Cichosza, Olecko 2001, s. 26.

${ }^{11}$ I. Lepalczyk, Helena Radlińska. Życie i twórczość, Toruń 2001, s. 137. 
ganizacji społecznych, osłabienie roli Kościoła katolickiego. W ich miejsce stworzono od podstaw nowe organizacje całkowicie podporządkowane władzom komunistycznym.

Tradycje polskiej opieki społecznej z lat przedwojennych uległy zatraceniu. Krytykowano działające w okresie międzywojennym organizacje za ich działalność w oparciu o miłosierdzie, sentyment i litość ${ }^{12}$. W konsekwencji zlikwidowano bądź upaństwowiono niemalże wszystkie podmioty zajmujące się wspieraniem potrzebującym - na przykład zlikwidowano CKOS, upaństwowiono kościelny Caritas, a Polski Czerwony Krzyż pozbawiony został swoich placówek leczniczych.

Cele opieki społecznej w porównaniu z okresem międzywojennym uległy zasadniczym przeobrażeniom. Z pola bezpośredniego zainteresowania wyszły osoby ubogie oraz ludzie z marginesu: żebracy, włóczędzy, prostytutki. Istnienie tychże beneficjantów opieki społecznej było skrzętnie marginalizowane, a jeżeli już o nim mówiono, to uznawane było za pozostałość ustroju kapitalistycznego. Socjalizm, który zdaniem jego propagatorów, likwidował źródła nędzy społecznej, czyli kryzys i bezrobocie, miał zagwarantować prawo do pracy wszystkim obywatelom, stąd trzymając się tej zasady, konsekwentnie odmawiano świadczeń osobom, które były zdolne do wykonywania zawodu. Opieka społeczna realizowana według tych zasad zajmowała się w pierwszej kolejności kierowaniem bezrobotnych do pracy, ,produktywizacją” osób z niepełnosprawnością (w tym inwalidów wojennych, ociemniałych), a także osób z marginesu przez przymusowe kierowanie do pracy. Dopiero w drugim rzędzie stały tradycyjne zadania opieki społecznej: ratownictwo w okresie klęsk żywiołowych oraz pomoc dla osób całkowicie niezdolnych do pracy. Zapomogi miały być stopniowo ograniczane do przypadków zupełnie wyjątkowych $^{13}$. Najbardziej optymistyczne głosy propagandy komunistycznej mówiły o docelowym zlikwidowaniu instytucji opieki społecznej wobec niewielkiej liczby osób wymagających wsparcia ${ }^{14}$.

Równolegle do osłabiania tradycyjnych form opieki społecznej wzmacnianiu ulegała pomoc socjalna dla pracowników zakładów państwowych. W 1948 r. powołano Fundusz Akcji Socjalnej, a referaty socjalne w zakładach pracy zajmowały się świadczeniem usług socjalnych dla pracowników i ich rodzin, takich jak: prowadzenie żłobków, przedszkoli, świetlic, organizowanie wczasów, ogródków działkowych ${ }^{15}$.

12 Por. G.E. Griffiths, Zagadnienie rehabilitacji, „Praca i Opieka Społeczna” 1948/2, s. 86.

13 Por. K. Rusinek, Zagadnienia pracy i opieki społecznej $w$ działalności Rad Narodowych, „Praca i Opieka Społeczna” 1950/1-2, s. 14-17.

14 Sendlerowa I., Dzieje rozwoju nowoczesnej opieki społecznej, „Opiekun Społeczny” 1947/2, s. 61-65.

15 M. Matraś, O zadaniach referatów socjalnych w roku 1952, „Przegląd Zagadnień Socjalnych”, 1952/4, s. $39-42$. 


\section{Odrodzenie opieki społecznej w duchu socjalizmu po roku 1956}

Pod koniec 1956 r. nastąpił zwrot polityczny w Polsce, zwany odwilżą październikową. Jego efektem było m.in. złagodzenie represji wobec osób niechętnych władzy, co przejawiło się uwolnieniem osób więzionych i internowanych, w tym prymasa Polski Stefana Wyszyńskiego. Zrewidowano także politykę gospodarczą kraju - zaprzestano kolektywizacji rolnictwa, pozwolono na ograniczony rozwój prywatnego rzemiosła, handlu i gastronomii, dążono do lepszego zaopatrzenia na rynku i poprawy warunków bytowych pracowników.

Mimo optymistycznych prognoz o zniknięciu problemów społecznych, osoby potrzebujące nadal funkcjonowały w społeczeństwie, a wśród wymagających pomocy coraz więcej było osób w podeszłym wieku oraz niepełnosprawnych ${ }^{16}$. Stąd też po 1956 r. nastąpiła liberalizacja dotychczasowej polityki państwa w zakresie ograniczania i umniejszania roli opieki społecznej. Konsekwentnie natomiast nie dopuszczano do aktywności w tym obszarze organizacji pozarządowych i religijnych.

Ważnym krokiem w odradzaniu się opieki i opieki społecznej było przywrócenie instytucji opiekuna społecznego. W 1959 r. ${ }^{17}$ powołano na niższych szczeblach samorządu opiekunów społecznych, mających organizować i koordynować akcję opieki społecznej przy współpracy z organami władzy i administracji państwowej, sądami, prokuraturą, zakładami pracy, szkołami, zakładami wychowawczymi, organizacjami społecznymi zajmującymi się działalnością opiekuńczą ${ }^{18}$. Zakres ich pracy obejmował: poprawę warunków materialnych, socjalnych i wychowawczych; pomoc dla dzieci i młodzieży pozbawionych właściwej opieki; pomoc rodzinom pozbawionych dochodu wskutek śmierci lub choroby jedynego żywiciela rodziny; walkę z alkoholizmem oraz prostytucją, opiekę nad osobami w podeszłym wieku' ${ }^{19}$.

Po odwilży roku 1956 r. rozpoczęła się w Polsce popularyzacja podporządkowanych władzy organizacji społecznych, również tych, które w statucie miały zapisane niesienie pomocy potrzebującym oraz szeroko rozumianą działalność socjalną. Miliony osób należących do organizacji masowych stały się stałym elementem propagandy PRL. Najczęściej jednak pomijano szczegółową charakterystykę struktury członków. Gdyby się jej bliżej przyjrzeć, to okazuje się, że bardzo często społecznicy należeli do kilku organizacji jednocześnie, z czego każdy podmiot wykazywał tę działalność (często dosłownie te same aktywności) w statystykach.

Wśród nowo powstałych organizacji należałoby wymienić Polski Komitet Opieki Społecznej, utworzony 7 maja 1958 r., który miał być organizacją uzupełniającą działal-

\footnotetext{
${ }^{16}$ A. Oleszczyńska, Pomoc społeczna w roku jubileuszu, „Opiekun Społeczny” 1979/2, s. 56.

17 Uchwała Nr 92 Rady Ministrów z dnia 5 marca 1959 r. w sprawie powołania opiekunów spolecznych, M. P. 1959, nr 32 poz. 145.

${ }_{18}$ Zob. F. Zieliński, Organizacja sieci terenowych Opiekunów Społecznych, „Biuletyn Opiekuna Społecznego" 1960/1, s. 33-34.

${ }_{19}$ Zob. K. Chaczko, „Polska w soczewce”. Ewolucja oraz modernizacja systemu... opieki i opieki spotecznej w perspektywie instytucjonalnej, „Rocznik Administracji Publicznej” 2016/2, s. 8-10.
} 
ność państwa w dziedzinie opieki społecznej. Podstawowy zakres aktywności obejmował uświadamianie oraz inicjowanie i organizowanie obywateli do świadczenia pomocy osobom potrzebującym, zwłaszcza starszym i niezdolnym do pracy ${ }^{20}$.

W 1960 r. powstało Polskie Towarzystwo Walki z Kalectwem - organizacja społeczno-naukowa, która przez kolejne dziesięciolecia znaczącą część swojej działalności poświęcała kwestiom pracy socjalnej z inwalidami. Głównymi obszarami je działalności były: profilaktyka inwalidztwa, rehabilitacja, organizacja zaplecza socjalnego dla inwalidów.

Kobiecą organizacją charakterystyczną dla okresu PRL była Liga Kobiet, która w zakresie swej działalności miała na przykład udzielanie bezpłatnej pomocy kobietom, znajdującym się w ciężkiej sytuacji, które nie były w stanie samodzielnie zaradzić swoim problemom $^{21}$.

Także w różnorodnych formach działalności prowadzonej przez członków Związku Harcerstwa Polskiego znajdowały się takie, które dotyczyły wspierania potrzebujących. Opierały się one na tradycyjnej, harcerskiej zasadzie „niesienia pomocy bliźnim”, a wśród aktywności podejmowanych przez harcerzy wymienić można udzielanie pomocy rolnikom w okresie żniw, niesienie pomocy starszym i chorym ${ }^{22}$.

Z kolei działalność charytatywna Kościoła, spełniająca wcześniej istotną rolę uzupełniającą dla systemu opieki społecznej, nie miała perspektyw na odrodzenie. Kwestie majątkowe pozostały niezmienione - zagrabione w okresie stalinowskim, wraz z budynkami i ziemią, szpitale, zakłady wychowawcze i oświatowe, szkoły, przedszkola, prowadzone przez Caritas, zakony, czy diecezje nadal pozostawały własnością państwa. Również po 1956 r. miały jeszcze miejsce kasaty majątków upaństwowionej już wtedy Caritas ${ }^{23}$. Władze zezwoliły jedynie na reaktywowanie niektórych stowarzyszeń charytatywnych oraz udzielanie pomocy wyłącznie przy parafiach ${ }^{24}$, jednakże większość katolickich organizacji dobroczynnych podzieliła losy innych stowarzyszeń związanych z Kościołem, którym nie pozwolono się odrodzić. Odwilż dla działalności Kościoła oznaczała także ograniczoną możliwość prowadzenia duszpasterstwa w szpitalach i sanatoriach ${ }^{25}$.

Natomiast działalność prowadziło upaństwowione Zrzeszenie Katolików Caritas, które administrowało zakładami opiekuńczo-wychowawczymi dla około 15 tysięcy osób, a także domami dziennego pobytu i kuchniami społecznymi. Wśród ponad 7 tysięcy osób zatrudnionych w Zrzeszeniu było 2300 sióstr i braci z 49 zgromadzeń zakonnych, 340 le-

${ }^{20}$ Pomoc spoleczna w Polsce, pod red. J. Staręgi-Piasek, cz. I, Warszawa 1984, s. 67-68.

${ }_{21}$ Zob. S. Zawadecka, O działalności Kół Gospodyń Wiejskich, „Nowe Drogi” 1960/3, s. 94-101.

22 W. Grzelak, P. Rządca, Drużyna i ja. Podręcznik drużynowego drużyny młodszoharcerskiej, Warszawa 1966, s. 15.

23 J. Żurek, Kościelny Październik '56, „Biuletyn Instytutu Pamięci Narodowej”, 2006/10, s. 75-76.

24 J. Krzyszkowski, Między państwem opiekuńczym a opiekuńczym społeczeństwem. Determinanty funkcjonowania środowiskowej pomocy społecznej na poziomie lokalnym, Łódź 2005, s. 55.

25 J. Żurek, op. cit., s. 75-76; J. Sikorski, Duszpasterstwo więzienne. Spojrzenie wstecz - rzeczywistość perspektywy, w: Kościół w Polsce wobec potrzebujacych, pod red. M. Chmielewskiego, Lublin 1994 , s. 202-203. 
karzy, 490 pielęgniarek, 950 wychowawców i ponad 1000 salowych $^{26}$. Działalność Caritas była w większej części finansowana przez państwo ${ }^{27}$.

Opieka społeczna po 1956 r., w myśl założeń ministerialnych, miała rozpocząć drogę do profesjonalizacji. Zarządzeniem Ministra Oświaty z dnia 4 listopada 1966 r. wprowadzono oficjalnie nazwę zawodu ,pracownik socjalny”28. Wprowadzenie nowego zawodu spowodowało, iż dodawano upowszechnianemu wtedy sformułowaniu „praca socjalna” cech różnych od dotychczas używanej nazwy „opieka społeczna”. Dążono, by zerwać z dobroczynnością na rzecz oparcia opieki społecznej o regularne finansowanie z budżetu państwa i profesjonalne działanie struktur społecznych ${ }^{29}$. Praktyczna realizacja wymienionych założeń napotykała często nieład organizacyjny i niedofinansowanie. Jednakże dążono do tego, by pracownik socjalny Polski Ludowej był docelowo pracownikiem budżetowym, wykonującym zawód profesjonalnie, będąc pewnym środków materialnych, jakimi dysponował w pomocy swoim klientom. Nie był natomiast ochotnikiem, gdyż ten model pracy socjalnej uważano już za przestarzały. Utworzenie nowego zawodu łączyło się z otwarciem w tym samym roku Państwowych Szkół Pracowników Socjalnych kształcących na poziomie średnim; pierwsze dwie szkoły powstały w Warszawie ${ }^{30}$ i Poznaniu ${ }^{31}$.

Przy okazji wprowadzenia do wykazu zawodów specjalności pracownik socjalny pojawiły się głosy o konieczności wysunięcia na pierwszy plan działalności społeczno-wychowawczej, ukierunkowanej na kształtowanie postaw zapobiegających lub niwelujących skutki niedostosowania społecznego. Działalność ta była rozumiana jako właściwe zaspokajanie potrzeb socjalnych, dobór odpowiedniej pracy, a także pomoc w sytuacjach kryzysowych przez fachowców (np. kuratorów, poradnie). Szczególną rolę w tym zakresie przypisywano opiece socjalnej ze strony zakładów pracy, która obejmowała organizowanie wolnego czasu, kolonii, ferii, działalność świetlic, placówek kulturalno-oświatowych, a także pomoc materialną w przypadkach losowych ${ }^{32}$.

${ }^{26}$ A. Rozciszewski, Powstanie i likwidacja Zrzeszenia Katolików Caritas, 2007, dostęp online z 1 września 2017 r. www.old.caritas.pl/zalacznik.php?id=78

27 Notatka w sprawie zakładów opieki społecznej prowadzonych przez „, Caritas”, Wydział Administracyjny KC PZPR, Warszawa, dn. 22 IV 1960 r., Archiwum Akt Nowych, zespół Polska Zjednoczona Partia Robotnicza, sygn. 237/XIV-180, k. 3.

${ }^{28}$ Zarządzenie Ministra Oświaty z dnia 4 listopada 1966 r. (Nr SZ2-0101-48/66) w sprawie zmiany nomenklatury zawodów i specjalności, do których przygotowują szkoły zawodowe, Dz. Urz. Min. Oświaty 1966, nr 16 poz. 193.

${ }_{29}$ Por. A. Kamiński, Funkcje pedagogiki społecznej. Praca socjalna i kulturalna, wyd. drugie poprawione i uzupełnione, Warszawa 1974, s. 75.

${ }^{30}$ Zob. C. Hibel, Dziesiąty rok kształcenia pracowników socjalnych w szkole warszawskiej, „Opiekun Społeczny" 1976/1, s. 9-15.

31 Zob. T. Bloch, Społeczno-wychowawcze funkcje szkoły pracowników socjalnych. Refleksje pedagogiczne w oparciu o doświadczenia szkoły poznańskiej, „Opiekun Społeczny” 1976/1, s. 29-33.

${ }^{32}$ A. Kowalska, Studium Stużb Społecznych i Wychowawczych Towarzystwa Wolnej Wszechnicy Polskiej, „Biuletyn TWWP” 1968/1, s. 163-164. 


\section{Opieka społeczna jako element systemu ochrony zdrowia}

Wprowadzony po 1956 r. system opieki społecznej, oparty na sieci opiekunów społecznych, okazał się niewydolny. Przyczyny tego zjawiska były dwojakie. Po pierwsze byli to pracownicy honorowi, wykonujący swoje obowiązki bezpłatnie i dobrowolnie, a takiego rodzaju stosunek pracy nie wystarczał do wywiązywania się z trudnych zadań, wymagających często natychmiastowego działania. Druga przyczyna leżała w wieku pracowników społecznych - w większości osób starszych, bez branżowego wykształcenia, niepotrafiących, mimo dobrych chęci, odpowiednio klasyfikować potrzeb i skutecznie interweniować. Pozyskiwanie młodych osób na te stanowiska nie przynosiło większych rezultatów ${ }^{33}$.

W kwietniu 1960 r. nastąpiła kolejna poważna zmiana w organizacji opieki społecznej. Zniesiono urząd Ministra Pracy i Opieki Społecznej, a dotychczasowe kompetencje Ministerstwa w zakresie opieki społecznej, rehabilitacji zawodowej inwalidów i przemysłu ortopedycznego przejęło nowo powołane Ministerstwo Zdrowia i Opieki Społecznej ${ }^{34}$. Była to niejako zapowiedź przeobrażeń, jakie dokonały się w kolejnej dekadzie, a polegających na łączeniu zadań opieki społecznej z opieką zdrowotną.

Lata 60. i 70. w PRL to okres włączania opieki społecznej w zakres usług medycznych. Uzasadniano go dużą wspólną grupą docelową obu systemów - osób w podeszłym wieku. Konieczność korzystania z opieki społecznej powodowana była często przyczynami zdrowotnymi osób starszych, które z uwagi na przemiany demograficzne stanowiły coraz liczniejszą grupę w populacji ${ }^{35}$. Osoby starsze oraz osoby z I i II grupą inwalidzką stanowiły aż 80\% wszystkich świadczeniobiorców opieki społecznej. Poza nimi klientami opieki społecznej były także rodziny ubogie, osoby cierpiące na przewlekłe schorzenia (np. gruźlicę, alkoholizm) oraz osoby z niepełnosprawnością intelektualną ${ }^{36}$.

Proces włączania opieki społecznej do systemu ochrony zdrowia pogłębił się w $1969 \mathrm{r}$. kiedy to utworzono ośrodki opiekuna społecznego, mieszczące się najczęściej przy medycznych przychodniach obwodowych. Celem powstania ośrodków była chęć usprawnienia współpracy pomiędzy służbą zdrowia a opieką społeczną, doszkalanie pracowników opieki, a w efekcie poprawa poziomu świadczeń opiekuńczo-zdrowotnych w środowisku lokalnym ${ }^{37}$. Rejonizacja obu typów świadczeń (pomocowych i medycznych) sprawiała, że powołany zespół środowiskowy (lekarz, pielęgniarki środowiskowe, pra-

33 T. Kaźmierczak, O wojewódzkich ośrodkach opiekuna społecznego - raz jeszcze, „Praca Socjalna” $1989 / 1$, s. 38-39.

${ }^{34}$ Zob. art. 13.3. Ustawy z dnia 13 kwietnia 1960 r. o utworzeniu Komitetu Pracy i Płac oraz o zmianach właściwości w dziedzinie ubezpieczeń społecznych, rent, zaopatrzeń i opieki społecznej, Dz. U. 1960 nr 20 poz. 119.

35 A. Oleszczyńska, [brak tytułu], „Opiekun Społeczny” 1974/ 2, s. 54.

${ }^{36}$ H. Chrostowska, Niektóre aspekty środowiskowej opieki społecznej, „Opiekun Społeczny” 1980/3, s. 20.

37 Zob. także: S. Rak, Rola i zadania ośrodka opiekuna społecznego, „Biuletyn Opiekuna Społecznego” 1969/3, s. 23; Instrukcja nr 1/69 Ministra Zdrowia i Opieki Społecznej z dnia 31 stycznia 1969 r. (CS 671-3/69) w sprawie ośrodka opiekuna społecznego, Dz. Urz. MZiOS z dn. 8 marca 1969 r. nr 4 poz. 12; A. Oleszczyńska, Pracownik socjalny w opieki społecznej, Warszawa 1978, s. 29. 
cownik socjalny) miał możliwość posiadania szerokiej wiedzy odnośnie osób potrzebujących, a w związku z tym mógł sprawnej reagować na powstające potrzeby ${ }^{38}$.

W rezultacie ośrodki, mające uzupełniać dotychczasowy system opieki społecznej, już po kilku latach swojej działalności wyraźnie go zdominowały, a co za tym idzie ,uzależniły" od służby zdrowia, czego jedną z konsekwencji było stopniowe zmniejszanie środków na opiekę społeczną na korzyść wydatków na opiekę zdrowotną ${ }^{39}$. Nie wszystkie ośrodki mogły funkcjonować zgodnie z założeniami. Władze lokalne i kierownicy przychodni medycznych często traktowali te ośrodki jako element drugorzędowy, co skutkowało brakami lokalowymi, materialnymi i organizacyjnymi, a tym samym uniemożliwiało sprawne podejmowanie zadań z zakresu opieki społecznejej.

Mimo wielu niedoskonałości proces przekształceń opieki społecznej w latach 70 . przyniósł znaczącą zmianę - działalność pracownika socjalnego uległa pewnej profesjonalizacji. Co prawda funkcjonowała jeszcze sieć opiekunów społecznych, działających na zasadach wolontariatu, jednakże główne zadania z zakresu opieki społecznej - diagnoza, plan pomocy i realizacja wsparcia należały już do etatowego, rejonowego pracownika (asystenta) socjalnego, zatrudnionego w ośrodku opiekuna społecznego ${ }^{41}$.

Lata 80 . w PRL były okresem kryzysu gospodarczego i jego konsekwencji - wyraźnego wzrostu liczby osób wymagających wsparcia. Znacząco pogorszyły się warunki życia ludności - wzrosły koszty utrzymania, drastycznie podniesiono ceny produktów (także żywnościowych), spadała siła nabywcza pieniądza. Pociągnęło to za sobą skokowy wzrost liczby osób korzystających z opieki społecznej, głównie w formie materialnej. Mimo postępujących zmian w obszarze zabezpieczenia społecznego, m.in. w zakresie upowszechnienia prawa do ubezpieczenia społecznego osób pracujących i ich rodzin, wciąż takie wsparcie materialne było ważnym elementem uzupełniającym dochody wielu gospodarstw domowych ${ }^{42}$.

Ostatnie lata PRL to niewątpliwy regres w dziedzinie opieki społecznej, związany z ogólną zapaścią i niewydolnością finansową państwa. Efektywność świadczeń opieki społecznej zdecydowanie spadła. Natomiast warto w tym miejscu podkreślić, że w ostatniej dekadzie PRL powstało bądź odrodziło się wiele inicjatyw pozarządowych niosących pomoc osobom potrzebującym, kompensujących niewydolność państwa w tym zakresie. Powstało wiele oddolnych inicjatyw związanych $\mathrm{z}$ niesieniem różnorodnej pomocy. Należy w tym miejscu wspomnieć m.in.: działalność Marka Kotańskiego, Towarzystwa Pomocy im. Adama Chmielowskiego, Komitetu Obrony Robotników, czy Wolnych Związków Zawodowych - mających w swoich postulatach także kwestie pomocy socjalnej.

38 Pomoc spoleczna $w$ Polsce, s. 46-48.

39 D. Zalewski, Opieka i pomoc społeczna. Dynamika instytucji, Warszawa 2005, s. 125.

40 S. Rak, Niektóre uwagi o działalności ośrodków opiekuna społecznego, „Opiekun Społeczny” 1971/1, s. $20-21$.

${ }^{41}$ K. Wódz, op. cit., s. 33-35; M. Śliwiński, Do opiekunów społecznych, „Opiekun Społeczny” 1979/2, s. 1; M. Karczewski, 20 lat ofiarnej i owocnej pracy, „Opiekun Społeczny” 1979/2, s. 6.

${ }^{42}$ D. Zaleski, op. cit., s. 125-126. 
Przykładem skutecznego niesienia pomocy wobec bezradności państwa jest z pewnością działalność Marka Kotańskiego. Wynalezienie stosunkowo prostych sposobów produkcji ,polskiej heroiny” i morfiny w 1976 r. oraz heroiny w 1979 r. ${ }^{43}$ poskutkował pojawieniem się w ciągu kilku lat przynajmniej kilkudziesięciu tysięcy osób uzależnionych ${ }^{44}$. Skutki rozpowszechniania narkomanii miały swoje dramatyczne konsekwencje w latach 80., kiedy zidentyfikowano wirus HIV, którego najczęstszą przyczyną rozpowszechniania było wówczas dożylne zażywanie narkotyków ${ }^{45}$. Pomoc narkomanom oferowana przez państwo polegała głównie na mało skutecznej hospitalizacji, a samo zjawisko narkomanii oficjalnie próbowano marginalizować. Nowy model terapii odwykowej stworzył Marek Kotański, który po kilku latach pracy z uzależnionymi w roku 1981 zarejestrował ośrodek pod nazwą „Monar”, w którym realizowano skuteczny program resocjalizacji osób uzależnionych od narkotyków, wykorzystujący metody nowatorskie, oparte o stwarzanie warunków kształtujących samodzielność, odpowiedzialność i zaangażowanie pacjentów.

\section{Podsumowanie}

Opieka społeczna w Polsce Ludowej (1944-1989) ulegała znaczącym przeobrażeniom, jednakże nie można o nich mówić jako o ciągłym rozwoju, czy nieustannej ewolucji tego systemu, czyli o ciągłych zmianach in plus. Realizowana przez komunistów polityka upaństwowienia wszelakich instytucji oraz likwidowania organizacji pozarządowych, doprowadziła do sytuacji, w której jedynym dysponentem pomocy potrzebującym było państwo. Niosło to za sobą fatalne konsekwencje. Odebrano Polakom możliwość organizowania się w stowarzyszenia niosące bezinteresowną pomoc, mimo iż tego typu działalność miała wielowiekową tradycję i niepodważaną skuteczność, nie tylko w wymiarze materialnym, ale i społecznym - jednoczyła w działaniu dużą część narodu.

Innym negatywnym skutkiem monopolistycznej polityki władz było zakorzenienie w części społeczeństwa trudnych do wyplenienia postaw roszczeniowych wobec państwa i jego organów. W praktyce zrezygnowano z proponowanego przez przedwojenną szkołę pracy społecznej rozumienia pomocy jako wsparcia, a nie wyręczenia, w chwilach trudnych dla jednostki. Ponadto rozwinięto, niekiedy do granic absurdu system świadczeń zakładowych, które z założenia miały wyrównać sytuację materialną najuboższych pracowników, a w praktyce doprowadziły do dalszego zróżnicowania i dodatkowego zwiększenia przywilejów osób na stanowiskach uprzywilejowanych.

Zarówno instytucjonalne, jak i społeczne prawidła działania systemu opieki społecznej w Polsce Ludowej wywarły wpływ na rozwiązania i problemy okresu III RP w tym

\footnotetext{
${ }^{43}$ D. Andrejew-Frączek, Narkomania w Polsce, „Biuro Studiów i Ekspertyz” 1992/19, s. 2.

${ }^{44}$ M. Kotański, Wstęp, [do] Problemy narkomanii. Zarys metod resocjalizacji i profilaktyki „,Monaru”, Warszawa 1984, s. 5-6.

45 A. Cybula i in., Najważniejsze pytania o HIV i AIDS, Poznań 2007, s. 13, 21.
} 
obszarze $^{46}$. Wśród odczuwalnych do dziś konsekwencji polityki społecznej PRL jest także stosunek do osób z niepełnosprawnością. Ówczesna ideologia uporczywie pomijała to zagadnienie, bądź koncentrowała się na niepełnosprawnych przodownikach pracy, czyli np. osobach bez ręki, które pracowały ponad normę. Nie ułatwiało to integracji osób niepełnosprawnych ze środowiskiem i stworzyło wiele ponadczasowych stereotypów.

Jednym z pomysłów władzy ,ludowej” na zreformowanie opieki społecznej było powiązanie jej z systemem ochrony zdrowia. W praktyce doprowadziło to zarówno do niedofinansowania opieki społecznej z uwagi na priorytetowość świadczeń zdrowotnych, jak i do skupienia się na świadczeniach bliskich służbie zdrowia.

Całościowe spojrzenie na dzieje opieki społecznej w latach 1944-1989 skłania także do pozytywnych wniosków. Są nimi niewątpliwie prowadzone po 1956 r. badania z zakresu nauk społecznych. Mimo konieczności dostosowania prac badawczych do warunków określonych przez władze, prężnie rozwijały się zakłady, instytuty, katedry i wydziały podejmujące tę tematykę w kolejnych ośrodkach akademickich.

W omawianym okresie następowała także pewna profesjonalizacja służb pracujących w placówkach opieki społecznej. Powstawały szkoły kształcące pracowników socjalnych na poziomie średnim, dawano im także możliwość podjęcia odpowiednio sprofilowanych studiów na uczelniach wyższych. Prowadzono kursy i szkolenia dokształcające, wydawano poradniki, czasopisma z przeznaczeniem dla opiekunów społecznych.

Nie ulega wątpliwości, że system opieki społecznej w Polsce Ludowej nie wywiązywał się w pełni ze swoich tradycyjnych zadań. Należałoby to łączyć z ogólnym stanem państwa. Jedną z bolączek Polski Ludowej, która dotyczyła także opieki społecznej, był niedobór kompetentnych urzędników - często pomoc była rozdysponowywana w sposób niewłaściwy, przez co nie docierała do najbardziej potrzebujących. Innym problemem był brak środków finansowych, który powodował zwlekanie z rozpoczęciem niektórych inwestycji (np. budowy domów opieki społecznej), przez co nie tylko zwiększało się grono osób pozostających bez właściwego wsparcia, ale też powstawały straty finansowe, np. z powodu braku miejsc w domach opieki społecznej osoby niepełnosprawne zajmowały łóżka szpitalne.

\section{Bibliografia}

Andrejew-Frączek D., Narkomania w Polsce, „Biuro Studiów i Ekspertyz” 1992/1.

Bloch T., Społeczno-wychowawcze funkcje szkoły pracowników socjalnych. Refleksje pedagogiczne w oparciu o doświadczenia szkoły poznańskiej, „Opiekun Społeczny” 1976/1.

Brenk M., Działania z zakresu ratownictwa spolecznego w Polsce w latach 1944-1948. „Biuletyn Historii Wychowania" 2014 (32).

Chaczko K., „Polska w soczewce”. Ewolucja oraz modernizacja systemu ... opieki i opieki społecznej w perspektywie instytucjonalnej, „Rocznik Administracji Publicznej” 2016/2.

Chrostowska H., Niektóre aspekty środowiskowej opieki społecznej, „Opiekun Społeczny” 1980/3.

\footnotetext{
46 Zob. R. Pląsek, Przemiany polskiego systemu opieki społecznej w latach 1945-1989, „Profilaktyka Społeczna i Resocjalizacja” 2014, nr 24, s. 96-97.
} 
Cichosz M., Pedagogika społeczna w Polsce w latach 1945-2005. Rozwój-obszary refleksji i badań - koncepcje, Toruń 2006.

Cybula A. i in., Najważniejsze pytania o HIV i AIDS, Poznań 2007.

Czyżowska Z., Świadczenia socjalne w czterdziestoleciu PRL, Warszawa 1987.

Griffiths G.E., Zagadnienie rehabilitacji, „Praca i Opieka Społeczna” 1948/2.

Grzelak W., P. Rządca, Drużyna i ja. Podręcznik drużynowego drużyny młodszoharcerskiej, Warszawa 1966.

Hibel C., Dziesiaty rok ksztatcenia pracowników socjalnych w szkole warszawskiej, „Opiekun Społeczny" 1976/1.

Instrukcja nr 1/69 Ministra Zdrowia i Opieki Społecznej z dnia 31 stycznia 1969 r. (CS 671-3/69) w sprawie ośrodka opiekuna społecznego, Dz. Urz. MZiOS z dn. 8 marca 1969 r. nr 4 poz. 12.

Kamiński A., Funkcje pedagogiki społecznej. Praca socjalna i kulturalna, wyd. drugie poprawione i uzupełnione, Warszawa 1974.

Karczewski M., 20 lat ofiarnej i owocnej pracy, „Opiekun Społeczny” 1979/2.

Karczewski M., Opieka społeczna, w: Polityka społeczna, pod red. A. Rajkiewicza, Warszawa 1979.

Kaźmierczak T., O wojewódzkich ośrodkach opiekuna społecznego - raz jeszcze, „Praca Socjalna” 1989/1.

Kotański M., Wstęp, [do] Problemy narkomanii. Zarys metod resocjalizacji i profilaktyki „,Monaru”, Warszawa 1984.

Kowalska A., Studium Stużb Społecznych i Wychowawczych Towarzystwa Wolnej Wszechnicy Polskiej, „Biuletyn TWWP” 1968/1.

Krzyszkowski J., Między państwem opiekuńczym a opiekuńczym społeczeństwem. Determinanty funkcjonowania środowiskowej pomocy społecznej na poziomie lokalnym, Łódź 2005.

Lepalczyk I., Helena Radlińska. Życie i twórczość, Torun 2001.

Manifest demokratycznych organizacji społeczno-politycznych i wojskowych w Polsce, w: Protokót Pierwszego Plenarnego Posiedzenia Krajowej Rady Narodowej, Warszawa 31 XII 1943 r. 1 I $1944 \mathrm{r}$.

Matraś M., O zadaniach referatów socjalnych w roku 1952, „Przegląd Zagadnień Socjalnych”, 1952/4.

Notatka w sprawie zakładów opieki społecznej prowadzonych przez „Caritas”, Wydział Administracyjny KC PZPR, Warszawa, dn. 22 IV 1960 r., Archiwum Akt Nowych, zespół Polska Zjednoczona Partia Robotnicza, sygn. 237/XIV-180.

Oleszczyńska A., [brak tytułu], „Opiekun Społeczny” 1974/ 2.

Oleszczyńska A., Pomoc społeczna w roku jubileuszu, „Opiekun Społeczny” 1979/2.

Oleszczyńska A., Pracownik socjalny w opieki społecznej, Warszawa 1978.

Opieka Społeczna 1944-1947, Wydawnictwo MPiOS, [1948], Archiwum Akt Nowych, zespół Ministerstwo Pracy i Opieki Społecznej w Warszawie, numer zespołu 402/0, sygn. 263.

Pląsek R., Przemiany polskiego systemu opieki społecznej w latach 1945-1989, „Profilaktyka Społeczna i Resocjalizacja” 2014 (24).

Pomoc spoleczna w Polsce, pod red. J. Staręgi-Piasek, cz. I, Warszawa 1984.

Poradnik Pracownika Socjalnego, pod red. Jana Rosnera, Warszawa 1973.

Protokót Pierwszego Plenarnego Posiedzenia Krajowej Rady Narodowej odbytego dnia 31 grudnia 1943 r. i w nocy z dnia 31 grudnia 1943 r. na 1 stycznia 1944 r., w: Protokót Pierwszego Plenarnego Posiedzenia Krajowej Rady Narodowej, Warszawa 31.XII.1943 r. - 1.I.1944 r.

Rak S., Niektóre uwagi o działalności ośrodków opiekuna społecznego, „Opiekun Społeczny” 1971/1.

Rak S., Rola i zadania ośrodka opiekuna społecznego, „Biuletyn Opiekuna Społecznego” 1969/3.

Rozciszewski A., Powstanie i likwidacja Zrzeszenia Katolików Caritas, 2007, dostęp online z 1 września 2017 r. www.old.caritas.pl/zalacznik.php?id=78. 
Rusinek K., Zagadnienia pracy i opieki społecznej w działalności Rad Narodowych, „Praca i Opieka Społeczna" 1950/1-2.

Sendlerowa I., Dzieje rozwoju nowoczesnej opieki społecznej, „Opiekun Społeczny” 1947/2.

Sikorski J., Duszpasterstwo więzienne. Spojrzenie wstecz - rzeczywistość - perspektywy, w: Kościót w Polsce wobec potrzebujacych, pod red. M. Chmielewskiego, Lublin 1994.

Smolińska-Theiss B., Pytania o pedagogike społeczna w PRL, w: Pedagogika społeczna. Tradycja - teraźniejszość - nowe wyzwania, pod red. E. Trempały, M. Cichosza, Olecko 2001.

Sprawozdanie z działalności Centrum Szkolenia Pracowników Opieki Społecznej w Łodzi za okres od dnia 15 maja 1945 r. do dnia 1 grudnia 1947 r., Archiwum Akt Nowych, zespół Ministerstwo Pracy i Opieki Społecznej w Warszawie, sygn. 134.

Śliwiński M., Do opiekunów społecznych, „Opiekun Społeczny” 1979/2.

Uchwała Nr 92 Rady Ministrów z dnia 5 marca 1959 r. w sprawie powołania opiekunów społecznych, M. P. 1959, nr 32 poz. 145.

Ustawa z dnia 13 kwietnia 1960 r. o utworzeniu Komitetu Pracy i Płac oraz o zmianach wtaściwości $w$ dziedzinie ubezpieczeń społecznych, rent, zaopatrzeń i opieki społecznej, Dz. U. 1960 nr 20 poz. 119.

Wódz K., Stużby społeczne w Polsce. Geneza, kierunki rozwoju, metody pracy, Katowice 1982.

Zalewski D., Opieka i pomoc społeczna. Dynamika instytucji, Warszawa 2005.

Zarzadzenie Ministra Oświaty z dnia 4 listopada 1966 r. (Nr SZ2-0101-48/66) w sprawie zmiany nomenklatury zawodów i specjalności, do których przygotowuja szkoły zawodowe, Dz. Urz. Min. Oświaty 1966, nr 16 poz. 193.

Zawadecka S., O działalności Kót Gospodyń Wiejskich, „Nowe Drogi” 1960/3.

Zieliński F., Organizacja sieci terenowych Opiekunów Społecznych, „Biuletyn Opiekuna Społecznego" 1960/1.

Żurek J., Kościelny Październik '56, „Biuletyn Instytutu Pamięci Narodowej”, 2006/10. 
